\title{
LOWER RESPIRATORY TRACT INFECTION CAUSED BY RESPIRATORY SYNCYTIAL VIRUS IN INFANTS: THE ROLE PLAYED BY SPECIFIC ANTIBODIES
}

\author{
Sandra E.Vieira ${ }^{1}$, Alfredo E. Gilio ${ }^{2}$, Edison L. Durigon ${ }^{3}$, Bernardo Ejzenberg ${ }^{1}$
}

Vieira SE, Gilio AE, Durigon EL, B Ejzenberg. Lower respiratory tract infection caused by respiratory syncytial virus in infants: the role played by specific antibodies. Clinics. 2007; 62(6):709-16.

INTRODUCTION: Respiratory syncytial virus (RSV) is a major etiological agent of lower respiratory tract infection in infants. Genotypes of this virus and the role of the infants' serum antibodies have yet to be fully clarified. This knowledge is important for the development of effective therapeutic and prophylactic measures.

OBJECTIVES: To evaluate the types and genotypes of RSV causing respiratory tract infection in infants, to analyze the association of subtype-specific serum antibodies with the occurrence of infection and to evaluate the presence of subtype-specific antibodies in the infants' mothers and their association with the profile of the childrens' serum antibodies.

METHODS: This was a prospective study on infants hospitalized with respiratory infection. Nasopharyngeal secretions were collected for viral investigation using indirect immunofluorescence and viral culture and blood was collected to test for antibodies using the Luminex Multiplex system. RESULTS: 192 infants were evaluated, with $60.9 \%$ having RSV (73.5\%- A and 20.5\% B). Six genotypes of the virus were identified: A5, A2, B3, B5, A7 and B4. The seroprevalence of the subtype-specific serum antibodies was high. The presence and levels of subtype-specific antibodies were similar, irrespective of the presence of infection or the viral type or genotype. The mothers' antibody profiles were similar to their infants'.

CONCLUSIONS: Although the prevalence of subtype-specific antibodies was elevated, these antibodies did not provide protection independently of virus type/genotype. The similarity in the profiles of subtype-specific antibodies presented by the mothers and their children was consistent with transplacental passage.

KEY WORDS: Respiratory. Syncytial. Antibody. Immunity. Infant.

\section{INTRODUCTION}

Respiratory Syncytial Virus (RSV) is a major cause of respiratory infection in infants. ${ }^{1}$ During the RSV season, it is estimated that about $40 \%$ of children will develop a lower respiratory tract infection (LRTI)..$^{2-5}$ Changes in airway immunity and/or integrity seem to play a role in the pathogenesis of this infection, as may be observed in vul-

1. Department of Pediatrics, Faculdade de Medicina, Universidade de São Paulo, Brazil.

2. Division of Internal Medicine, Hospital Universitário, Universidade de São Paulo, Brazil.

3. Department of Virology, Instituto de Ciências Biomédicas, Universidade de São Paulo, Brazil.

Email: sandra@hu.usp.br

Received for publication on May 23, 2007

Accepted for publication on August 30, 2007 nerable groups, such as neonates, premature infants and those with congenital or acquired immunodeficiencies or cardiac or respiratory conditions..$^{5-7}$ However, approximately $70 \%$ of the infants hospitalized due to RSV-LRTI do not present these risk factors, ${ }^{6}$ therefore indicating the potential involvement of other variables. One important aspect is the role of serum antibodies, as RSV-LRTI primarily affects children in their first months of life, when their serum level of maternal anti-RSV antibodies is high. It is possible, however, to provide adequate protection against RSVLTRI with the prophylactic use of immunoglobulins (RSV$\mathrm{Ig}$ ) or monoclonal antibodies in infants. ${ }^{8-11} \mathrm{~A}$ reasonable explanation would be the lack of specificity of the maternal antibodies to the RSV genotype (subtype) infecting the infant, due to the known fact that circulating genotypes of 
RSV in a current season are substituted for others a few years later; therefore, the serum maternal antibodies at the time of infection would not correspond to the current infecting genotype, but rather to genotypes from previous years. ${ }^{12,13}$ In order to test this hypothesis, the authors identified the type/genotype of the RSV detected in infants with LRTI, and evaluated the presence and amount of serum subtype-specific antibodies for the RSV genotype responsible for the infection. Additionally, anti-RSV antibodies were measured in the sera of the mothers of infants with LRTI.

This knowledge will hopefully contribute to the development of prophylactic measures, including active immunization.

\section{SAMPLES AND METHODS}

This prospective study was approved by the Ethics and Research Committees of the University Hospital of the Universidade de São Paulo. Parents or legal guardians signed the Informed Consent.

From March 1999 to June 2000, infants admitted at the University Hospital were selected according to the following inclusion criteria: younger than one year of age, duration of the respiratory condition of seven days or less, LRTI diagnosis at admission, and hospitalization between Monday to Thursday (due to operational reasons). LRTI was determined by clinical parameters, which consisted of one or more of the following findings: snores, wheezing and crackles, and by radiological parameters, which in turn consisted of one or more of the following findings: diffuse pulmonary hyperinflation, alveolar condensation, and pulmonary interstitial infiltration. ${ }^{3,14}$ The main exclusion criterion was an inconclusive result in the immunofluorescence assay, defined as a fluorescence pattern distributed randomly on the slide, but lacking the characteristic appearance of RSV.

Two hundred and three patients met the inclusion criteria and 11 were excluded. The sample of 192 patients was distributed into two groups: infants infected with RSV (RSV+), and infants with negative findings for RSV (RSV-), the last being considered the control group. Table 1 shows the demographics of the sample.

Selected patients were submitted to collection of respiratory secretions by means of a nasal swab in one nare and by nasopharyngeal aspirate in the other nare. ${ }^{15}$ Material was collected within the first 24 hours after hospital admission.

A three milliliter blood sample was drawn from all patients within the first 48 hours of hospitalization for analysis of RSV-specific serum antibodies. Biological mothers who were at the hospital in the first 48 hours after the admission of their infants also had a sample drawn to undergo the same analysis.
Table 1 - Demographic characteristics and diagnosis status of the RSV positive and negative groups.

\begin{tabular}{|c|c|c|c|c|c|c|c|}
\hline \multirow{3}{*}{$\begin{array}{l}\text { Characteristic } \\
\begin{array}{l}\text { Mean age +/- SD } \\
\text { (months) }\end{array}\end{array}$} & \multirow{2}{*}{\multicolumn{2}{|c|}{$\begin{array}{c}\mathrm{RSV}+ \\
117 \text { cases } \\
4.7+/-4.3\end{array}$}} & \multirow{2}{*}{\multicolumn{2}{|c|}{$\begin{array}{c}\text { RSV - } \\
75 \text { cases } \\
5.6+/-3.7\end{array}$}} & \multicolumn{2}{|c|}{$\begin{array}{c}\text { Total } \\
192 \text { cases }\end{array}$} & \multirow{3}{*}{$\begin{array}{c}\mathrm{p} \\
0.13\end{array}$} \\
\hline & & & & & 5.0 & (4.1) & \\
\hline & $\mathrm{N}$ & $(\%)$ & $\mathrm{N}$ & $(\%)$ & $\mathrm{N}$ & $(\%)$ & \\
\hline \multicolumn{8}{|l|}{ Gender } \\
\hline Male & 65 & $(55.6)$ & 38 & $(50.7)$ & 107 & $(55.7)$ & 0.51 \\
\hline Female & 52 & (44.4) & 37 & (49.3) & 85 & (44.3) & \\
\hline Well-Developed* & 88 & (75.2) & 53 & (70.7) & 141 & (73.4) & 0.49 \\
\hline \multicolumn{8}{|l|}{ Diagnosis } \\
\hline Bronchiolitis & 57 & $(48.7)$ & 18 & $(24.0)$ & 75 & $(39.1)$ & 0.01 \\
\hline Pneumonia & 18 & (15.4) & 30 & $(40.0)$ & 48 & $(25.0)$ & 0.04 \\
\hline $\begin{array}{l}\text { Bronchiolitis and } \\
\text { pneumonia }\end{array}$ & 16 & (13.7) & 6 & $(8.0)$ & 22 & (11.5) & 0.23 \\
\hline Wheezing & 8 & $(6.8)$ & 8 & $(10,7)$ & 16 & $(8,3)$ & 0,35 \\
\hline $\begin{array}{l}\text { Wheezing and } \\
\text { pneumonia }\end{array}$ & 18 & (15.4) & 13 & $(17.3)$ & 31 & (16.1) & 0.72 \\
\hline
\end{tabular}

\section{Laboratorial processing of respiratory secretion samples}

Clinical laboratory tests were performed at the Virology Laboratory of the Center for Disease Control in Atlanta, GA, USA, for determination of RSV genotype and specific antibodies, and at the XXX Virology Laboratory of Instituto de Ciências Biomédicas in São Paulo, SP, Brazil, for viral isolation.

The media containing the swab and aspirate materials were homogenized and the samples were separated into aliquots for inoculation into cell cultures, indirect immunofluorescence and storage. The cell culture media utilized were Hep2, Hela-1 and NCI-H292. Indirect immunofluorescence was performed both directly on the collected material and on the culture-seeded material. Indirect immunofluorescence assay tests and specific monoclonal antibodies for RSV, influenza viruses $\mathrm{A}$ and $\mathrm{B}$, parainfluenza viruses 1,2 and 3 and adenovirus were used, according to pre-established techniques (Chemicon International ${ }^{\circledR}$ commercial kit). Two specific monoclonal antibodies were used for identifying the epitopes of the RSV isolates: Mab 92 11 for type A, and Mab 102-10b for type B.

\section{Genotyping of RSV isolates}

Viral RNA was extracted using guanidinium-isothiocyanate-phenol (RNAzol; Teltest, Friendswood ${ }^{\mathrm{R}}, \mathrm{TX}$ ). RNA was annealed with $20 \mathrm{mM}$ F1 primer and reverse-transcribed with avian myeloblastosis virus reverse transcriptase (Boehringer Mannheim). The PCR assay was carried out following cDNA synthesis. The cDNA resulting from this process was submitted to two PCR reactions in order to 
amplify distinct genes: gene $\mathrm{F}$, without significant variability, and gene $\mathrm{G}$, which allows for the classification of the viral genotypes due to its gene sequence variability. $12,16,17$

\section{Phylogenetic Analysis}

The products obtained from RSV genome sequencing were submitted to the Molecular Evolutionary Genetics Analysis (MEGA) program version 1.02, which analyzes similarities and calculates the genetic distance among sequences, and also to phylogenetic analysis using parsimony and other methods (Phylogenetic Analysis Using Parsimony* Program - version 4.0 Beta - Sinauer Associates, Inc.), an instrument for inference and analysis of phylogenetic trees based on the methods of parsimony and genetic distance. ${ }^{12,16}$

\section{Identification of specific subtype antibodies in serum samples}

The anti-RSV antibodies studied were: anti-A1, anti-A2, anti-A3, anti-A4, anti-A5, anti-A6, anti-A7, anti-B1, antiB4 and anti-B. The Luminex Multiplex System (Austin, TX) was used to identify specific subtype antibodies for the g1 and g2 regions of the RSV G protein. This method consists of mixing the patient's blood sample with a solution containing specific RSV genotype antigens coupled to microspheres. The identification of antigen-bound antibody was carried out using another biotin-labeled and streptavidinfluorescein-tagged antibody, Readings were performed with FACScan, which provides the average sample fluorescence. In order to detect the presence of each subtype-specific antibody in the serum, the fluorescence index (FI) was used. Jones et al have previously described this method based on analysis of sample fluorescence in comparison to negative controls. The FI is considered positive if it is equal to or greater than $3 .{ }^{18}$

\section{STATISTICAL ANALYSIS}

Means and ratios were used to evaluate demographic and clinical variables. The Student's t test was applied to compare means, the Chi-square and Fisher's exact tests were used to examine relationships among variables, the homogeneity Chi-square test was used to compare seroprevalence, and one-way analysis of variance (ANOVA) was used to determine the association between the amount of antibodies and the occurrence of infection. In order to correct for the distortion observed due to the obtained results' amplitudes, FIs were transformed into natural loga- rithms $(\log \mathrm{FI})$ and their means were compared. Poisson regression was applied to evaluate the correlation between the antibody means and the occurrence of infections, logistic regression was used to determine the cutoff point of the levels of anti-A2 and anti-A5 antibodies, and Spearman's coefficient was used to study the correlation between the prevalence of antibody in the infants and in their mothers. The significance level was set at $5 \%$ and the confidence intervals were set at $95 \%$. The statistical software packages Excel 2000, SAS 8.0 and SPSS 10.0 were utilized. ${ }^{19,20}$

\section{RESULTS}

The RSV(+) group consisted of 117 infants, of which $86(73.5 \%)$ had RSV A and 24 (20.5\%) had RSV B. The RSV type was not identified in seven $(6 \%)$ patients. The genotypes identified in 71 positive samples were: GA5 (28 samples), GA2 (21 samples), GA7 (one sample), GB3 (17 samples), GB5 (three samples), and GB4 (one sample). In the RSV(-) group, which included 75 infants, influenza A (two samples) and adenovirus (one sample) were identified.

In $172(89.6 \%)$ infants, some subtype-specific antibodies against antigen A were identified, while in 153 infants (79.7\%) some subtype-specific antibodies against antigen B were identified. The subtype-specific antibodies anti-A2, anti-A1 and anti-A5 were the most prevalent $(80.7 \%$, $56.2 \%$, and $44.8 \%$, respectively). The prevalence of the other antibody subtypes were: anti A3 $-8.8 \%$, anti A4 $13.5 \%$, anti $\mathrm{A} 6-11.5 \%$, anti $\mathrm{A} 7-11.5 \%$, anti $\mathrm{B} 1-17.1 \%$ and anti B4 $-20.3 \%$. The majority of the anti-B antibodies were not subject to subtype categorization $(75 \%)$.

The seroprevalences of anti-A and anti-B antibodies in infants with RSV A and RSV B infections, and also in the RSV(-) group, were similar. Likewise, the seroprevalences of subtype-specific antibodies were similar in these three groups (Table 2).

The prevalence of subtype-specific antibodies evaluated in children infected by the RSV genotypes GA2, GA5 and GB3 and in those belonging to the RSV (-) group were all similar. In addition, the Anti-2 and Anti-5 subtype-specific antibodies were found in children infected by the GA2 and GA5 RSV genotypes (Table 3).

The amount of serum subtype-specific antibodies to RSV (means of $\log$ FI) in infants infected with RSV A, RSV B and in the RSV(-) group were found to be similar between the three groups. Similar results were obtained in analysis for the RSV genotype A2-, A5- and B3-infected groups, as well as for the RSV (-) group (Table 4).

Logistic regression was applied to examine the potential existence of a serum level of antibodies against the RSV genotypes A2 and A5 that would be sufficient to protect in- 
Vieira SE et al.

Table 2 - Prevalence of specific RSV antibodies: anti-A, anti-B and subtype-specific antibodies according to the viral status detected in the sera of infants with LRTI.

\begin{tabular}{|c|c|c|c|c|c|c|c|}
\hline \multirow{2}{*}{$\begin{array}{l}\text { RSV-specific } \\
\text { antibodies }\end{array}$} & \multicolumn{2}{|c|}{ Infection byRSV A N=86 } & \multicolumn{2}{|c|}{ Infection byRSV $\mathrm{B} N=24$} & \multicolumn{2}{|c|}{ RSV negativeN $=75$} & \multirow[t]{2}{*}{$\mathrm{P}$} \\
\hline & $\mathrm{N}$ & $(\%)$ & $\mathrm{N}$ & $(\%)$ & $\mathrm{N}$ & $(\%)$ & \\
\hline Anti-A* & 71 & $(82.6)$ & 20 & $(83.3)$ & 67 & $(89.3)$ & 0.88 \\
\hline Anti $^{\#} \mathrm{~A} 1$ & 47 & $(54.7)$ & 16 & $(66.7)$ & 45 & $(60.0)$ & 0.54 \\
\hline $\mathrm{A} 2$ & 69 & $(80.3)$ & 20 & $(83.3)$ & 66 & $(88.0)$ & 0.41 \\
\hline A3 & 09 & $(10.5)$ & 01 & $(4.2)$ & 07 & $(9.3)$ & 0.64 \\
\hline A4 & 12 & $(14.0)$ & 05 & $(20.8)$ & 09 & $(12.0)$ & 0.56 \\
\hline A5 & 38 & $(44.2)$ & 14 & $(58.3)$ & 34 & $(45.3)$ & 0.46 \\
\hline A6 & 10 & $(11.6)$ & 02 & $(8.3)$ & 10 & (13.3) & 0.80 \\
\hline A7 & 10 & $(11.6)$ & 02 & $(8.3)$ & 09 & $(12.0)$ & 0.88 \\
\hline Anti-B* & 65 & $(75.6)$ & 21 & $(87.5)$ & 58 & $(77.3)$ & 0.33 \\
\hline Anti $^{\#}$ B1 & 14 & (16.3) & 05 & (20.8) & 14 & (18.7) & 0.85 \\
\hline B4 & 15 & (17.4) & 04 & (16.7) & 20 & (26.7) & 0.31 \\
\hline Anti B not cat** & 65 & $(5.6)$ & 21 & $(87.5)$ & 58 & $(77.3)$ & 0.33 \\
\hline
\end{tabular}

* Serum antibodies for RSV-specific type

\# subtype-specific antibodies

** not classified in categories

Table 3 - Prevalence of anti-RSV subtype-specific antibodies in the sera of infants infected with the most frequently found RSV genotypes.

\begin{tabular}{|c|c|c|c|c|c|}
\hline \multirow{4}{*}{$\begin{array}{l}\text { Anti-RSV subtype-specific } \\
\text { antibodies* }\end{array}$} & \multicolumn{3}{|c|}{ RSV genotype } & \multirow{4}{*}{$\begin{array}{c}\text { RSV(-) } \\
\text { N=75 } \\
\text { N (\%) }\end{array}$} & \multirow{4}{*}{$P$} \\
\hline & $\mathrm{A} 2$ & A5 & B3 & & \\
\hline & $\mathrm{N}=21$ & $\mathrm{~N}=28$ & $\mathrm{~N}=17$ & & \\
\hline & $\mathrm{N}(\%)$ & $\mathrm{N}(\%)$ & $\mathrm{N}(\%)$ & & \\
\hline Anti A1 & $12(57.1)$ & $14(50.0)$ & $12(70.5)$ & $45(60.0)$ & 0.59 \\
\hline Anti A2 & 15 (71.4) & $24(85.7)$ & $14(82.3)$ & $66(88.0)$ & 0.32 \\
\hline Anti A3 & 03 (14.2) & $01(3.5)$ & $00(0.0)$ & 07 ( 9.3$)$ & 0.31 \\
\hline Anti A4 & 03 (14.2) & $04(14.2)$ & 03 (17.6) & 09 (12.0) & 0.94 \\
\hline Anti A5 & $06(28.5)$ & $14(50.0)$ & $10(58.8)$ & $34(45.3)$ & 0.28 \\
\hline Anti A6 & $03(14.2)$ & $02(7.1)$ & $00(0.0)$ & $10(13.3)$ & 0.36 \\
\hline Anti A7 & 03 (14.2) & $01(3.5)$ & $00(0.0)$ & 09 (12.0) & 0.25 \\
\hline Anti B1 & $02(9.5)$ & $08(28.5)$ & $04(23.5)$ & 14 (18.6) & 0.39 \\
\hline Anti B4 & $02(9.5)$ & 09 (32.1) & 02 (11.7) & $20(26.6)$ & 0.16 \\
\hline Anti B n.cat. ** & 15 (71.4) & $21(75.0)$ & $16(94.1)$ & $58(77.3)$ & 0.35 \\
\hline
\end{tabular}

$\mathrm{N}$ - \# of cases $* *$ - not classified in categories

Table 4 - Estimates of the amounts of anti-RSV subtype-specific antibodies in the sera of infants with RSV GA2, GA5, GB3 and in the RSV(-) group.

\begin{tabular}{|c|c|c|c|c|c|}
\hline ANTIBODIES & $\begin{array}{c}\mathrm{FI}^{\#} \text { - VSR A2 } \\
\text { Med (IQI) }\end{array}$ & $\begin{array}{c}\mathrm{FI}^{\#} \text { - VSR A5 } \\
\text { Med (IQI) }\end{array}$ & $\begin{array}{c}\mathrm{FI}^{\#} \text { - VSR B3 } \\
\text { Med (IQI) }\end{array}$ & $\begin{array}{c}\mathrm{FI}^{\#}-\mathrm{RSV}(-) \\
\text { Med (IQI) }\end{array}$ & $\mathrm{P}^{*}$ \\
\hline Anti A1 & $3.6(1.1-6.2)$ & $2.6(1.7-4.7)$ & $4.0(2.0-6.0)$ & $3.5(1.9-5.5)$ & 0.81 \\
\hline Anti A2 & $6.6(2.6-10.1)$ & $5.6(3.3-8.7)$ & $8.3(4.3-9.9)$ & $6.9(3.7-12.9)$ & 0.61 \\
\hline Anti A3 & $0.7(0.1-1-3)$ & $0.4(0.2-0.7)$ & $0.3(0.2-0.6)$ & $0.3(0.1-0.9)$ & 0.61 \\
\hline Anti A4 & $0.5(0.2-1.4)$ & $0.7(0.2-1-5)$ & $0.7(0.5-1.7)$ & $0.6(0.3-1.4)$ & 0.81 \\
\hline Anti A5 & $1.6(0.8-4.0)$ & $3.2(1.0-6.1)$ & $4.1(1.9-5-9)$ & $2.9(1.1-6.0)$ & 0.61 \\
\hline Anti A6 & $0.3(0.1-0.6)$ & $0.2(0.1-0.4)$ & $0.2(0.1-0.4)$ & $0.2(0.1-1.0)$ & 0.44 \\
\hline Anti A7 & $0.3(0.2-0.8)$ & $0.4(0.3-0.9)$ & $0.5(0.3-1-4)$ & $0.5(0.2-1.7)$ & 0.93 \\
\hline Anti B1 & $0.5(0.4-1.3)$ & $1.0(0.7-3.0)$ & $0.8(0.5-2.7)$ & $0.8(0.4-2.0)$ & 0.37 \\
\hline Anti B4 & $0.4(0.2-1.4)$ & $0.8(0.2-3.3)$ & $0.5(0.3-1.0)$ & $0.5(0.2-2.3)$ & 0.57 \\
\hline Anti B n.cat $* *$ & $5.9(2.1-16.8)$ & $13.0(4.4-25.7)$ & $7.7(4.4-14.2)$ & $7.9(3.2-22.3)$ & 0.50 \\
\hline
\end{tabular}

\# FI= Fluorescence Index Med=median IQI =Interquartile interval (0.25-0.75)

$* \mathrm{P}$ of the mean of the natural $\log$ of the FI **n.cat. = not categorized 
fants against LRTI related to those genotypes. The FI log means for the anti-A2 antibody in infants infected with the RSV genotype GA2 in comparison with the other genotypes and also with the RSV(-) control group were similar ( $\mathrm{P}=$ 0.98). Likewise, the means of the log FI of the anti-A5 antibody in infants infected with RSV genotype GA5, in infants infected with the other genotypes and in infants from the RSV(-) group were similar $(\mathrm{P}=0.73)$.

Poisson regression was applied to compare the number of RSV subtype-specific antibodies in infants with LRTI due to RSV A and RSV B, as well as in the RSV(-) group. The mean numbers of anti-A subtype-specific antibodies for the three groups were 2.24, 2.46 and 2.36, respectively, whereas the mean numbers of anti-B subtype-specific antibodies were $1.09,1.25$ and 1.19 , respectively. Results were similar, regardless of the detection of the virus or RSV type.

All mothers presented specific antibodies against RSV A and RSV B. Anti-A1 and anti-A2 antibodies were the most prevalent. Infants presented a lower percentage of all subtype-specific antibodies in comparison to their mothers. However, the ratio of the prevalence in infants in relation to the prevalence in mothers varied according to the different antibodies. There was a strong correlation between the prevalence of each subtype-specific antibody in infants and in their mothers (Spearman's coefficient $=0.896, \mathrm{P}=$ 0.001) (Figure 1).

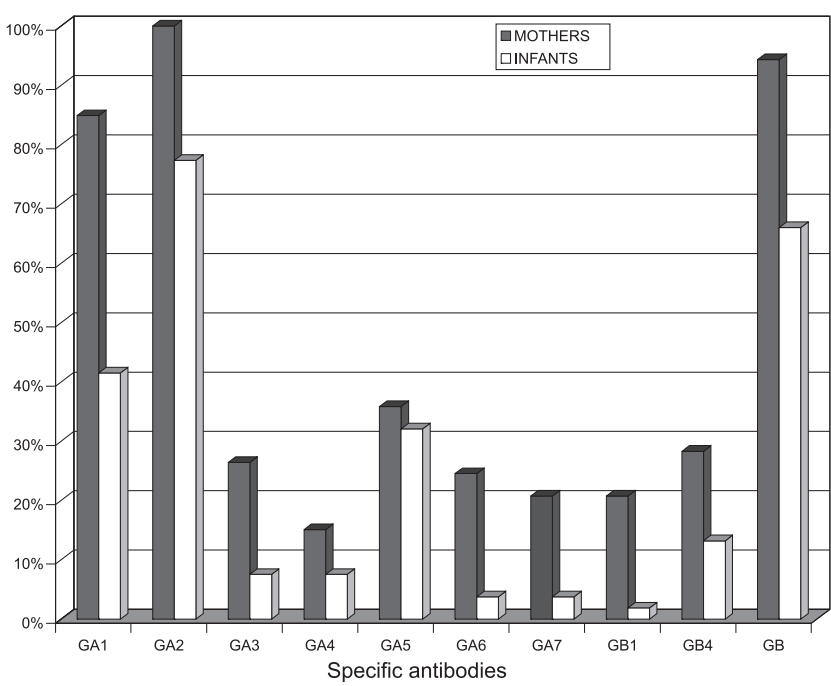

Figure 1 - Prevalence of anti-RSV specific antibodies in the sera of infants with LRTI and of their mothers.

\section{DISCUSSION}

The high rate of RSV isolates $(61 \%)$ is similar to that observed in infants during the RSV season in several countries. ${ }^{2-4}$ Infants admitted with severe RSV-LRTI presented the usual clinical patterns characteristic of this population
- a few months in age and predominantly suffering from bronchiolitis rather than bronchopneumonia (Table 1). ${ }^{2,21}$

RSV A was predominant, as verified in different regions of the world. The predominant genotypes were A5, A2 and B3, and these also represented the most frequently encountered in other regions of the world, such as in South Africa, Uruguay and Argentina. ${ }^{22-24}$ The association of immunofluorescence and culture for RSV rendered high sensitivity to the diagnostic method. Although the possibility exists of false negative results from our method which might be identified by the use of RT-PCR, the known difference in sensitivity between these methods does not suggest that the interpretations of our results or the conclusions of this study would be altered with the use of RT-PCR. ${ }^{25,26}$

The serum antibody doses from the initial phase of the disease reflect the contents of the serum prior to the acquisition of infection. The results suggest that these antibodies were acquired by passive transference because the patients' ages (median of five months) and infection severity are characteristic of a first contact with $\mathrm{RSV}^{21}$. Previous seroprevalence studies have shown that anti-RSV maternal antibodies remain in the infants' blood during this specific period of their lives, gradually decreasing until the sixth to seventh month of life. ${ }^{8}$ An evaluation of antibodies during the convalescence phase was not performed in this study. This approach would certainly provide relevant information with regards to the infants' response to infection.

The presence of subtype-specific antibodies for RSV A and RSV B did not protect infants from RSV-related LRTI, as shown by the high and similar seroprevalence of some anti-A and anti-B antibodies in both the RSV(+) and RSV(-) groups. Immunofluorescence was applied in these assessments as it is considered a sensitive and specific assay suitable for detection of subtype-specific antibodies to RSV. ${ }^{18}$

The role of subtype-specific antibodies in protection against LRTI caused by the corresponding genotype could be evaluated only for the anti-A2 and anti-A5 antibodies. The anti-A2 and anti-A5 antibodies did not protect against LRTI caused by the RSV genotypes GA2 and GA5, respectively. Seventy-one percent of infants infected with genotype GA2 presented the anti-A2 antibody, while $50 \%$ of those infected with genotype GA5 presented the anti-A5 antibody. The prevalence of these two antibodies was also similar in children infected with other genotypes and in patients of the RSV (-) group (Table 2).

Although a high percentage of the infant samples presented the anti-A1 antibody, there was no infection caused by this genotype, which could possibly suggest its protective effect. Nevertheless, seasonal variations of the genotype cannot be ruled out. In fact, the latter seems to adequately explain the low prevalence of anti-A7 and anti- 
B4 antibodies in the sample without concomitantly elevated prevalence of their corresponding genotypes.

All the facts mentioned above aid us in our understanding the ethiopathogenesis of LRTI caused by RSV. At least for infections caused by genotypes GA2 and GA5, the most common in our sample, we were not able to confirm the hypothesis that LRTI would be caused by genotypes against which infants do not present specific serum immunity. There is little information available about the role played by subtype-specific antibodies in protecting infants from RSV infections. McGill et al. examined maternal and infant immunity against subtype A lineages of RSV responsible for infant infections in the United Kingdom. ${ }^{27}$ By using indirect immunofluorescence and inoculation of the virus responsible for the infection, they found that infants, their mothers, and uninfected children (control group) presented antibodies specific to the genotype that caused the infection. ${ }^{27}$

Quantitative analysis of specific antibodies is very relevant once large amounts of passively administered antibodies (by intra-muscular or endovenous means) to newborns and infants provide effective protection against RSV-LRTI ${ }^{10,11}$. Additionally, groups with higher serum titers of anti-RSV antibodies are better protected against LRTI, as is the case observed for health care workers and older children. ${ }^{21,27}$ Another finding in this study was that the quantity of maternal antibodies was higher than in infants. Nevertheless, this aspect was not fully explored because the applied method was a semi-quantitative one that renders quantification of this difference difficult. Quantitative assessment of subtype-specific antibodies for RSV in infants was limited by this method, and thus these results should be interpreted with caution. ${ }^{18}$

Higher amounts of subtype-specific antibodies against RSV, taking into account the natural variation encountered in infants, did not provide protection against LRTI caused by the corresponding viruses, as the means of the FI values of the anti-A and anti-B antibodies were similar in the RSV A, RSV B and RSV(-) groups. Additionally, the viral genotypes GA2 and GA5 infected infants regardless of the FI of the anti-A2 and anti-A5 antibodies (Table 6). In a different analysis, no cut-off points were identified above which subtype-specific anti-A2 and anti-A5 antibodies protected against infection caused by the corresponding genotype.

One possible explanation for the absence of protection attributed to higher amounts of specific antibodies would be that the titers of specific antibodies naturally encountered in infants of few months in age are extremely low. This fact may be corroborated by comparison with antibody titers obtained with the use of monoclonal antibodies in other studies. This comparison, however, is not feasible due to diverse antibody quantification methods.

Altogether, the observed data suggest that serum-specific anti-RSV antibodies, most probably maternally acquired, do not fully protect infants from RSV-related LRTI. This conclusion is supported by strong clinical evidence since the peak of RSV-related LRTI occurs in the first few months of life, when the levels of maternal immunoglobulins are at their highest. Unfortunately, confirmation of the hypothesis that LRTI occurs due to the lack of subtype-specific antibodies to fight the infecting genotype was compromised. It was also not possible to clarify other confounding factors which may potentially be involved in the pathophysiology of RSV-related LRTI, such as airway immunity status, environmental pollution, viral load and low socioeconomic levels of the families. . $^{1321,28,29}$

\section{CONCLUSIONS}

Type and subtype-specific serum antibodies encountered naturally do not provide specific protection against LRTI caused by RSV groups A or B or by the genotypes GA2, GA5 and GB3 in infants. This finding was observed in spite of the elevated seroprevalence of serum genotype-specific antibodies against RSV. In order to corroborate these interesting findings, these results should be re-examined in other regions of the world, as well as for other genotypes and subtype-specific antibodies.

Acknowledgements: The authors would like to acknowledge the collaboration of Dr. Larry J. Anderson, Dr. Teresa Peret, and Dr. Cecília Tsou, all members of the CDC.

\section{RESUMO}

Vieira SE, Gilio AE, Durigon EL, B Ejzenberg. Infecção por virus sincicial respiratório: o papel dos anticorpos séricos específicos. Clinics. 2007; 62(6):709-16.
INTRODUÇÃO: O vírus sincicial respiratório é um dos principais agentes etiológicos das infecções do aparelho respiratório inferior em lactentes. Os genótipos deste vírus e 
o papel dos anticorpos séricos ainda não estão esclarecidos. Este conhecimento é importante para o desenvolvimento de medidas terapêuticas e profiláticas.

OBJETIVOS: Avaliar: os tipos e genótipos do vírus sincicial que causam infecção respiratória em lactentes e a associação dos anticorpos séricos subtipo-específicos com a ocorrência de infecção; a presença de anticorpos subtipo-específicos nas mães e sua associação com o perfil de anticorpos da criança. MÉTODOS: Estudo prospectivo incluindo lactentes hospitalizados com infecção respiratória. Foi coletada secreção de nasofaringe para investigação viral usando imunofluorescência indireta e cultivo viral. Foi coletado sangue para pesquisa de anticorpos usando o sistema Luminex Multiplex.

RESULTADOS: Avaliados 192 lactentes: 60,9\% com vírus sincicial $(73,5 \%$ - A e 20,5\% - B). Seis genótipos de vírus sincicial respiratório foram identificados: A5,A2,B3,B5,A7 e B4. A soroprevalência dos anticorpos subtipos-específicos foi alta. A presença e o nível de anticorpos subtiposespecíficos foram semelhantes, independentemente da presença de infecção, tipo e genótipo do vírus. As mães e as crianças apresentaram perfis semelhantes de anticorpos. CONCLUSÕES: A prevalência dos anticorpos subtiposespecíficos foi elevada mas estes anticorpos não conferiram proteção, independentemente do tipo/genótipo do vírus. A semelhança dos perfis de anticorpos das mães e das crianças foi compatível com transmissão transplacentária.

UNITERMOS: Respiratório. Sincicial. Anticorpo. Imunidade. Crianças

\section{REFERENCES}

1. Ogra PL. Respiratory syncytial virus: the virus, the disease and the immune response. Paeditr Respir Rev. 2004;5:S119-26.

2. Vieira SE, Stewien KE, Queiroz DA, Durigon EL, Torok TJ, Anderson $\mathrm{LJ}$, et al. Clinical patterns and seasonal trends in respiratory syncytial virus hospitalization in São Paulo, Brazil. Rev Inst Med Trop Sao Paulo. 2001;43:125-31.

3. Stensballe LG, Devasundaram JK, Simoes EAF. Respiratory syncytial virus epidemics: ups and downs of a seasonal virus. Pediatr Infect Dis J. 2003;22:S21-32.

4. Myao CR, Vieira SE, Gilio AE, Hein N, Pahl MMC, Betta SL, et al. Infecções virais em crianças internadas por doença aguda do trato respiratório inferior. J Pediatr (Rio J). 1999;75:334-43.
5. Collins PL, Chanock RM, Murphy BR. Respiratory syncytial virus. In: Fields BN, Knipe DM, Howley PM. Fields virology. 4th ed. Philadelphia: Lippincott-Raveen Publishers; 2001.

6. Meissner HD, Rennels MB, Pickering LK, Hall CB. Risk of severe respiratory syncytial virus disease, identification of high risk infants and recommendations for prophylaxis with palivizumab. Pediatr Infect Dis J. 2004;23:284-5

7. Shay DK, Holman RC, Newman RD, Liu LL, Stout JW, Anderson LJ. Bronchiolitis-associated hospitalizations among US children, 1980-1996. JAMA. 1999;282:1440-6.

8. Cox MJ, Azevedo RS, Cane PA. Seroepidemiological study of respiratory syncytial virus in Sao Paulo state, Brazil. J Med Virol. 1998;55:234-9. 
9. Groothuis JR, Simoes EAF, Levin MJ, Hall CB, Long CE, Powell KR, et al. RSVIG Study Group Respiratory Syncytial virus immune globulin prevents severe lower respiratory tract illness in high risk infants. N Engl J Med. 1993;329:1524-30.

10. PREVENT Study Group. Reduction of respiratory syncytial virus hospitalization among premature infants with virus bronchopulmonary dysplasia using respiratory syncytial virus immune globulin prophylaxis. Pediatrics. 1997;99:93-9.

11. Impact-RSV Study Group. Palivizumab, a humanized respiratory syncytial virus monoclonal antibody, reduces hospitalization from respiratory syncytial virus infection in high risk infants. Pediatrics. 1998;102:531-7.

12. Peret TCT, Hall CB, Hammond GW, Piedra PA, Storch GA, Sullender WN, et al. Circulation patterns of group A and B human respiratory syncytial virus genotypes in 5 communities in North America. J Infect Dis. 2000;81:1891-6.

13. Brandenburg AH, Neijins HJ, Osterhaus ADME. Pathogenesis of RSV lower respiratory tract infection: implications for vaccine development. Vaccine. 2001;19:2769-2782.

14. WHO. Management of childhood ilness. Geneve: World Health Organization; 1995.

15. Hein N, Santos NC, Cacharro AL, Lopes CLBC, Gomes MCS, Durigon EL, Gilio AE,Ejzenberg B. A coleta simultanea de swab nasal e de aspirado de nasofaringe para pesquisa de virus respiratórios em crianças hopitalizadas.Pediatria (São Paulo) 2003; 25(3): 84-90

16. Peret TCT, Hall CB, Schanabel KC, Golub JA, Anderson LJ. Circulation patterns of genetically distinct group A and B strains of human respiratory syncytial virus in a community. J Gen Virol. 1998;79:2221-9.

17. Chomczynski P. Single-step method of RNA isolation by acid guanidium thiocyanate-phenol-chloroform extraction. Anal Biochem. 1987;162:156-9.

18. Jones LP, Zheng H, Karron RA, Peret TCT, Tsou C, Anderson LJ. Multiplex Assay for detection of strain-specific antibodies against the two variable regions of the $\mathrm{G}$ protein of respiratory syncytial virus. Clin Diagn Lab Immunol. 2002;9:633-8.
19. McCullagh P, Nelder JA. Generalizer Linear Models. 2nd ed. London: Chapman \& Hall; 1989.

20. Neter J, Kutner M, Nachtsheim C. Wasserman W. Applied Linear Statistical Models. 4th ed. Ilinois; 1996. p.1408

21. Hall CB. Respiratory syncytial virus. In: Feigin RD. Textbook of pediatric infectious diseases. 4th ed. Philadelphia: Saunders; 1998. p. 2084-111.

22. Venter M, Madhi SA, Tiemessen CT, Schoub BD. Genetic diversity and molecular epidemiology of respiratory syncytial virus over four consecutive seasons in South Africa: identification of new subgroup A and B genotypes. J Gen Virol. 2001;82:2117-24.

23. Frabasile S, Delfraro A, Facal L, Videla C, Galiano M, de Sierra MJ, et al. Antigenic and genetic variability of human respiratory syncytial virus (group A) isolated in Uruguay and Argentina: 1993-2001. J Med Virol. 2003;71:305-12.

24. Galiano MC, Palomo C, Videla CM, Arbiza J, Melero JA, Carballal G. Genetic and antigenic variability of human respiratory syncytial virus (groups A and B) isolated over seven consecutive seasons in Argentina (1995 to 2001). J Clin Microbiol. 2005;43:2266-73.

25. Storch GA. Diagnostic virology. In: Fields BN, Knipe DM, Howley PM. Fields virology. 4th ed. Philadelphia: Lippincott-Raveen Publishers; 2001.

26. Ray CG, Minnich LL. Efficiency of immunofluorescence for rapid detection of common respiratory viruses. J Clin Microbiol. 1987;25:355-7.

27. McGill A, Greensill J, Craft AW, Fenwick F, Toms GL. Measurement of antibody against contemporary virus lineages of human respiratory syncytial virus subgroup A in infants and their mothers. J Clin Virol. 2004;30:73-80.

28. Purcell K, Fergie J. Driscoll Children's Hospital respiratory syncytial virus database: risk factors, treatment and hospital course in 3308 infants and young children, 1991 to 2002. Pediatr Infect Dis J. 2004;23:418-23.

29. Englund JA, Sullivan CJ, Jordan MC, Dehner LP, Vercellotti GM, Balfour HH. Respiratory syncytial virus infection in immunocompromised adults. Ann Int Med. 1998;109:203-8. 